\title{
GAYA TILAWAH JAWI MUHAMMAD YASER ARAFAT
}

\author{
Tika Puspita Sari ${ }^{1}$ \\ Pengkajian Seni Musik, \\ Program Pascasarjana Institut Seni Indonesia \\ Jl. KH. Hadjar Dewantara, No. 19 Kentingan Jebres Surakarta, \\ 57126 Telp. (0271) 647658, Fax. 646175 \\ tika.puspitarussalis@gmail.com
}

\begin{abstract}
Artistic talent, passion, and social support from the surrounding are the main factors which shape Yaser's consistency in going through his life as artist - tilawah jawi reciter. Yaser gives contribution by creating a new masterpiece, which is reciting Al-Qur'an by infusing Javanese music in his tilawah without breaking the rule of tajwid. Yaser is a creative artist as proven by the creating of new form and new style in the art of Al-Qur'an recitation by changing maqamat arabiyah system with laras pelog nem.
\end{abstract}

Key Words: Artistry; Musical style; Creative

\begin{abstract}
ABSTRAK
Bakat artistik, semangat, dan dukungan sosial dari sekitarnya adalah faktor utama yang membentuk konsistensi Yaser dalam menjalani hidupnya sebagai seorang seniman - pelafalan jawi. Yaser memberikan kontribusi dengan menciptakan karya baru, yaitu membaca Al-Qur'an dengan memasukkan musik Jawa dalam bacaannya tanpa melanggar aturan tajwid. Yaser adalah seniman kreatif sebagai bentuk bentuk baru dan gaya baru dalam seni pembacaan dengan mengubah sistem maqamat arabiyah dengan laras pelog nem.
\end{abstract}

Kata Kunci: Seni; Gaya musik; Kreatif

Gaya seni menurut Edi Sedyawati dalam Sukerta merupakan bentuk yang tetap, serta senantiasa berulang dalam hal membentuk dan menyajikan karya seninya (Sukerta, 2004: 54-55). Selanjutnya I Wayan Rai S. dalam Sukerta secara lebih spesifik menjelaskan, bahwa gaya (khususnya dalam karya seni) itu memiliki karakteristik di antaranya keunikan, originalitas, dan beberapa karakteristik lainnya (Sukerta, 2004: 398). Kedua penjelasan tersebut selanjutnya menjadi landasan penting untuk mengungkap gaya Yaser. Hal-hal yang perlu dilakukan di awal adalah mengkaji karya Yaser dan mengamati pertunjukan Yaser. Setelah itu membandingkan dengan objek yang sama, sehingga pada akhirnya ditemukan gaya Yaser dalam kesenian ini.

Karya seni merupakan bagian dari kreativitas seseorang, Amabile dalam Rasita menyatakan bahwa kreativitas tidak hanyabergantung pada kemampuan kognitif dan keterampilan teknis seseorang dalam berfikir kreatif, tetapi juga dipengaruhi oleh motivasi intrinsik (pendorong internal) dalam bekerja, dan pada lingkungan sosial yang kondusif (pendorong eksternal) (Rasita, 2005: 122). Dalam pembentukan gaya musikal Yaser, kepribadian, latar belakang, dan pengalaman hidup Yaser yang menjadikan tialawah sebagai bentuk pembelaan terhadap tersingkirnya nada-nada pribumi (Laras Jawa), menjadi stimulan yang kuat dalam proses penciptaan dan penyajian karyanya tilawah jawi) (Yaser, wawancara 2 Juli 2015). Sikap Yaser yang merasa perlunya melakukan pembelaan terhadap nada-nada yang terpinggrikan tercermin dalam bentuk karya dan penyajiannya. Untuk melihat hal tersebut secara eksplisit Waridi menjelaskan bahwa, gaya dalam konteks berkesenian digunakan untuk menyebut ciri permainan atau ekspresi seorang seniman dalam memainkan instrumen atau melahirkan karya-karya ciptanya (Waridi, 2008: 38). Beberapa pengertian pgaya tersebut digunakan dalam melihat gaya Yaser dalam kesenian ini.

\section{A. Analisis Gaya Tilawah Jawi Yaser}

Fokus pada kajian ini dikupas satu persatu, apa yang menjadi ciri permainan Yaser dalam tilawah 
jawi. Terdapat tiga elemen penting yang akan dikaji dalam gaya musik Yaser pertama adalah vokal internal yang terdiri dari dua unsur qira'at yang digunakan dan aturan tajwid yang berlaku. Kedua Elemen lagu dalam vokal eksternal yang terdiri dari nada, laras, phatet dan seleh. Kolaborasi dari kedua elemen ini menghasilkan rangkaian nada yang membentuk sebuah kalimat lagu (frasa). Kalimat lagu yang telah dibentuk akan terdidentifikasi cengkok yang dibentuk dari beberapa teknik.

\section{Analisis Repetisi dan Pemisahan Teks}

Terciptanya rima pada setiap akhir ayat alQur'an tidak dapat dilepaskan dari aturan taksin, yaknimematikan bunyi huruf pada setiap waqaf (Stwart, 2001:478). Uraian selanjutnya akan menjelaskan mengenai Repetisi atau pemisahan teks.

1. Repetisi

Repetisi atau pengulangan ayat pada surah al-Isra dilakukan sebanyak dua kali seperti yang ditampilkan pada gambar berikut ini:

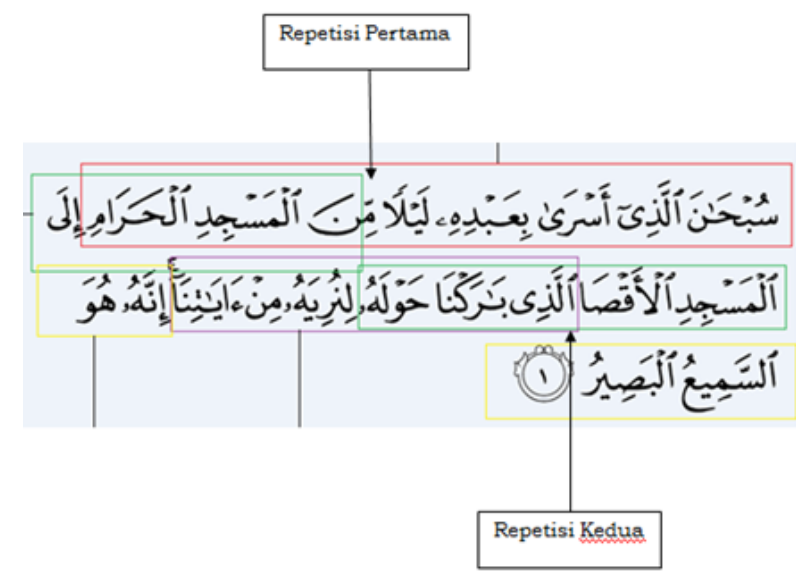

Gambar 1. Repetisi Surah al-Isra

Pemenggalan ayat tentu tidak boleh dilakukan disembarang tempat karena akan mengaburkan makna yang terkandung dalam ayat tersebut, walaupun pada kenyataanya tilawah selalu ditampilkan dengan pembacaan sari tilawah. Berikut ini adalah frasa yang dihasilkan dari hasil repetisi beserta makna yang terkandung di dalamnya.

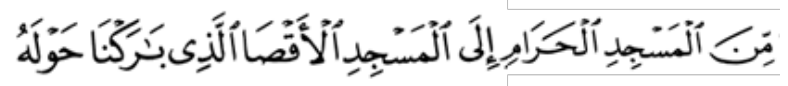

Artinya: pada suatu malam dari masjidil haram, kemasjidil aqsa yang telah kami berkahi sekelilingnya,

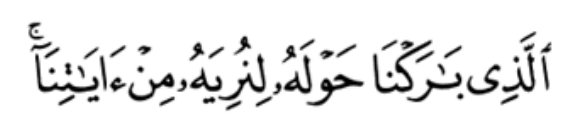

Artinya: yang telah kami berkahi sekelilingnya agar kami perlihatkan kepadanya tanda-tanda (kebesaran) Kami,

Dapat disimpulkan bahwa tidak terdapat pengaburan makna dalam repetisi yang dilakukan Yaser, dari dua pengulangan tersebut Yaser memberhentikan huruf pada tempat yang benar, sehingga makna yang terkandung dalam isi bacaan masih terjaga.

\section{Pemisahan Teks}

Susunan dasar dalam melantunkan tilawah adalah sebuah frasa yang kemudian diikuti dengan jeda (pause). Seorang Qari' diperbolehkan mengakhiri frase lagunya pada titik manapun selama hal ini tidak mengaburkan atau merusak makna dari teks yang dibaca. Hal ini telah diantisipasi dalam aturan tajwid tentang waqaf dan ibtidah. Secara umum frase yang lebih panjang adalah ciri khas dari resitasi mujjawad karena hal ini memberikan kesempatan bagi Qari' dalam mengeksplorasi lagu menggunakan skill modulasi atau sekedar untuk menunjukan ketahanan nafasnya yang panjang. (Akbar, 2009:143).

Teknik penyusunannya adalah dengan cara menghadirkan teks pendek tanpa hiasan (unornamented) terlebih dahulu kemudian teks diulang dalam satu frase panjang. Urutan frase yang pendek adalah tanda bahwa teks tersebut akan dielaborasi dengan lagu dalam satu nafas panjang. Efek dari teknik ini adalah untuk meningkatkan keterlibatan audien dengan menunda resolusi yang tersedia dalam frase yang lebih panjang. Semakin banyak rangkaian frase pendek semakin lama pula keteganan ini berlangsung hal ini secara tidak langsung menambahkan elemen retorik dan dramatik ke dalam sebuah resitasi (Akbar,2009:143).

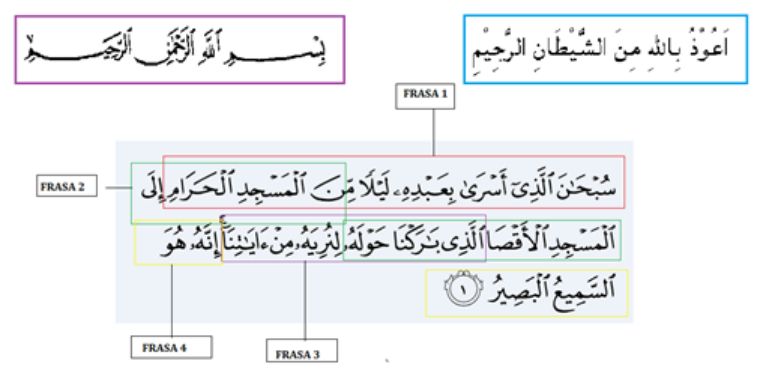

Gambar 2. Pemisahan Teks pada Surat al-Isra Pemisahan teks yang dilakukan Yaser pada 
surah al-Isra menghasilkan empat frasa. Pemisahan teks dilakukan karena pertimbangan nafas, karena Surat al-Isra atau surat Bani Israil ayat 1 dapat dikategorikan sebagai ayat yang panjang.

Pemenggalan ayat tentu tidak boleh dilakukan disembarang tempat karena akan mengaburkan makna yang terkandung dalam ayat tersebut, walaupun pada kenyataanya tilawah selalu ditampilkan dengan pembacaan sari tilawah. Berikut ini adalah frasa yang dihasilkan Yaser serta makna yang terkandung dalam setiap frasanya.

\section{1) Frasa pertama al-Isra ayat 1}

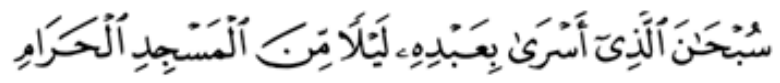

Artinya: mahasuci Allah yang telah memperjalankan hamba-Nya pada suatu dari masjidil haram,

\section{2) Frasa kedua al-Isra ayat 1}

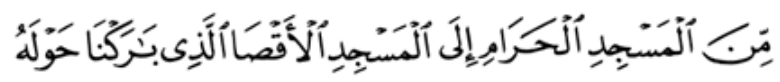

Artinya: dari masjidil haram ke masjidil aqsa yang telah kami berkahi sekelilingnya,

\section{3) Frasa ketiga al-Isra ayat 1}

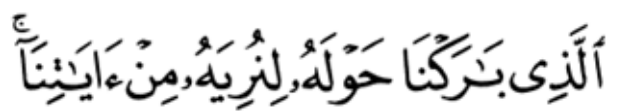

Artinya: yang telah kami berkahi sekelilingnya agar kami perlihatkan kepadanya tanda-tanda (kebesaran) Kami,

\section{4) Frasa keempat al-Isra ayat 1}

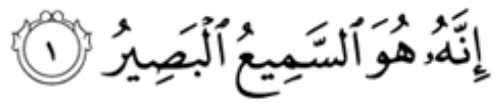

Artinya,sesungguhnya Dia adalah Maha Mendengar lagi Maha Melihat.

Dapat disimpulkan bahwa tidak terdapat pengaburan makna dalam pemisahan teks yang dilakukan Yaser, dari empat frasa tersebut Yaser memberhentikan huruf pada tempat yang benar.

\section{Analisis Kualitas Suara}

Kualitas suara merupakan hal pertama yang akan disinggung ketika membicarakan seorang Qari'. Para Qari' dikenal dan diingat melalui kualitas suaranya, elemen ini penting karena turut menggambarkan reputasi seorang Qari'. Muamar, seorang Qari' internasional yang jaya pada tahun 1982 memiliki perincian mengenai kriteria kualitas suara. (1) bila suara memenuhi empat tangga nada, mulai dari qarar hingga jawab bul jawab dengan tidak terpaksa, (2) bila suara tersebut bening, halus, merdu serta memiliki getaran yang mulus, tidak serak dan kotor, (3) bila suara tersebut mudah diatur, tidak fals atau sumbang, (4) mempunyai stamina yang tinggi, sanggup tanpa cacat dalam waktu yang relatif lama, (5) vokalnya tepat identik dengan dialek bahasa Arab, (6) tepat, sesuai dengan jenis dan golongannya. Untuk seorang Qari' laki-laki tidak terlalu kecil suaranya, sebaliknya jika perempuan maka memiliki suara yang lebih feminim.

Enam kriteria yang telah dipaparkan Muammar tersebut selanjutnya digunakan untuk melihat kualitas Yaser, penilaian dilakukan oleh para ahli yang memiliki kapasitas untuk memberikan penilaian, akan tetapi

\section{a) Tangga Nada}

Hasil analisis pada surah al-Isra dan an-Najm diketahui bahwa Yaser memiliki jangkauan nada yang cukup luas nada terendah Yaser adalah $A b 2$ dan nada tertinggi berada pada $\mathrm{A} b 4$.

Seperti yang terlihat pada tabel berikut:

Tabel 1. Frekuensi jangkauan nada Yaser pada Tilawah Jawi

\begin{tabular}{|c|c|c|}
\hline Nama & Nada & Frekuensi \\
\hline \multirow{2}{*}{$\begin{array}{c}\text { Nem }(\mathrm{nm}) \\
6\end{array}$} & $\mathrm{~A} b 2$ & 104,92 \\
\cline { 2 - 3 } & $\mathrm{A} b 3$ & 207,31 \\
\cline { 2 - 3 } & $\mathrm{A} b 4$ & 415,47 \\
\hline
\end{tabular}

Pada tabel tersebut dapat dilihat bahwasannya Yaser mampu menjangkau nada $\mathrm{A} b 4$, namun sebetulnya Yaser memiliki jangkauan nada yang sangat luas. Hal ini diketahui saat Yaser melakukan resitasi dengan tilawah arabi yaitu dengan maqam nahawand. Diketahui frekuensi nada Yaser mencapai C\#5 yaitu 526 hertz. 


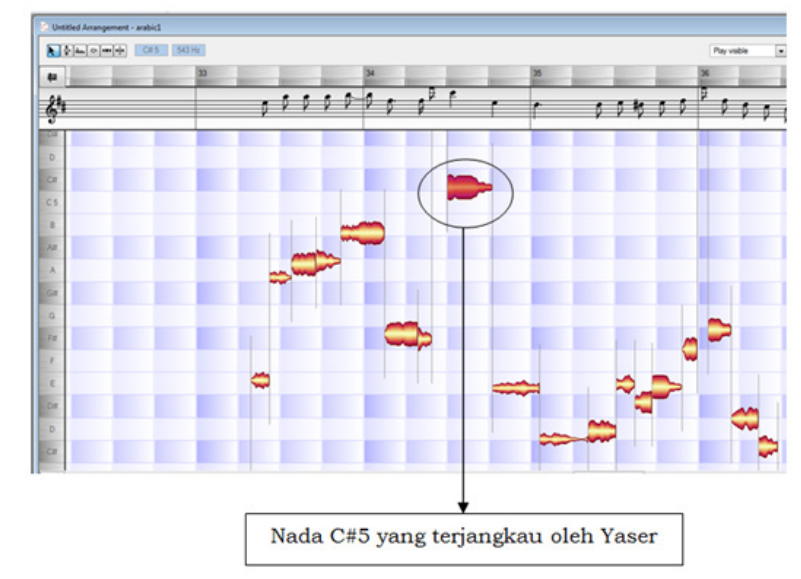

Gambar 3. Jangkauan nada tertinggi Yaser

\section{b) Kejernihan}

Setiap Qari' tentu memiliki karakter suara yang berbeda-beda, dalam hal ini karakter suara Yaser dapat dikatakan memiliki suara yang sedikit serak, namun tidak dapat dikategorikan dalam suara yang seserak suara seorang Rocker ketika menyanyi.Selain itu Yaser juga memiliki suara yang sedikit sengau seperti suara yang dikuelurakan oleh orang saat menutup hidungnya. Satu pernyataan menarik dari Yaser bahwa ketika dia berbicara atau bernyanyi, biasanya ada saja temannya yang "meledek" Yaser dengan pernyataan seperti ini:

...kalau saya menyanyi biasanya temanteman saya meledek dengan kalimat seperti ini: "mbok "ainnya gak usah dibawa-bawa ngaji kok di Qori' in..." (Yaser, wawancara 18 Agustus 2016).

Pernyataan tersebut tidak hanya dituturkan Yaser, namun juga berdasarkan observasi langsung. Saat berbicara biasa suara Yaser memang terdengar sedikit sengau seperti orang yang terkena flu. Audio Yaser saat berbicara biasa dapat didengarkan pada file audio.

\section{c) Tidak fals}

Melihat kemampuan dan kemahiran Yaser dalam mengolah sebuah melodi ataupun memainkan musik maka sudah dapat dipastikan Yaser tidak memiliki suara yang sumbang atau fals. Dinyatakan tidak fals atau sumbang bukan berarti Yaser memiliki suara yang pasti (absolude pitch). Namun intensitas dan kestabilan adalah hal yang dapat menunjukkan suara yang tidak sumbang. Berikut gambaran visual dengan bantuan software celemony melodyne.

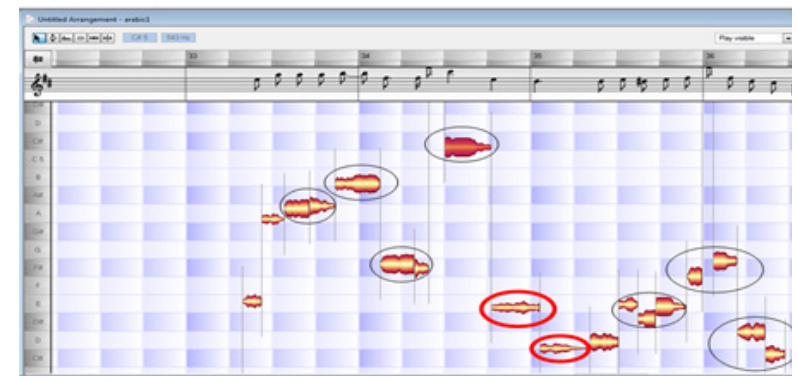

Gambar 4. Grafik yang menunjukkan intensitas suara Yaser

Pada gambar tampak grafik suara Yaser memiliki intensitas ketebalan yang hampir sama, ini memperlihatkan bahwa Yaser memiliki power yang cukup kuat, hal tersebut menunjukkan bahwa stamina yang dimiliki Yaser juga baik.

\section{d) Stamina}

Stamina seorang Qari' dapat dilihat berdasarkan kestabilan suaranya. Sejak dimulai resitasi hingga selesai, Yaser dapat dikatakan memiliki stamina yang baik. Tingkat kestabilan Yaser dalam membaca juga tetap.

Saat berada pada jangkauan nada-nada rendah grafik menunjukkan gambar yang tebal, sedangkan saat bersuara tinggi grafik terlihat tipis. Satu hal yang perlu diperhatikan adalah bahwa dalam satu tarikan nafas grafik menunjukkan intensitas yang sama. Berikut gambaran visualnya

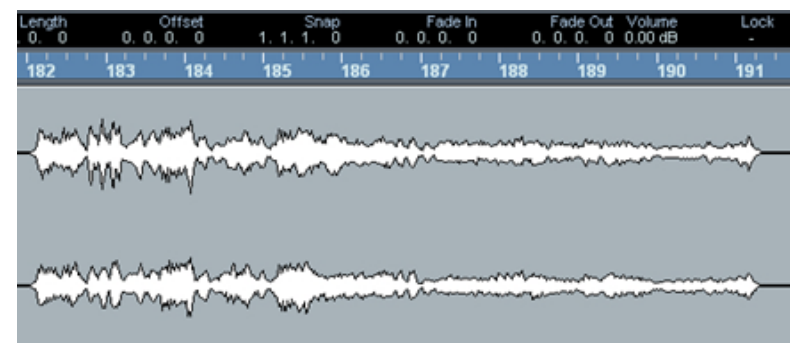

Gambar 5. Suara Yaser pada nada rendah

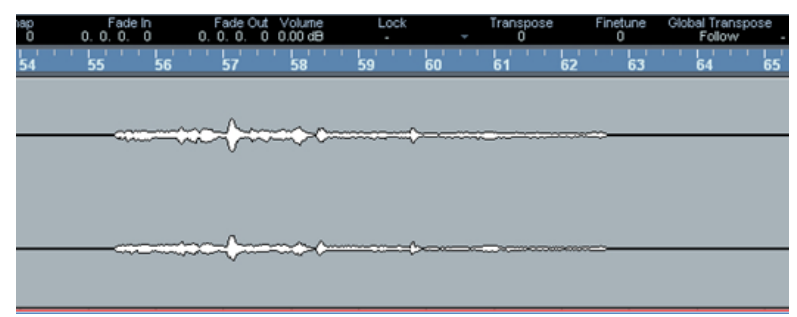

Gambar 6. Suara Yaser pada nada rendah

Sebagai data pendukung untuk dapat melihat intensitas suara Yaser yang cukup stabil digunakan software celemony melodyne. Jenis 
software ini sesungguhnya tidak untuk keperluan penotasian, namun karena kemampuannya dalam memvisualkan nada ke dalam notasi balok dan dapat menunjukkan posisi nada dalam kotak-kota nada yang tersedia pada gambar. Kiranya cukup membantu untuk menjelaskan suara Yaser yang tidak fals atau sumbang.

\section{e) Lahjah Arab}

Yaser dalam resitasinya telah menempatkan huruf sesuai haknya, seperti yang dinyatakan Sinungjanutama bahwa bacaan Yaser sesungguhnya masih sangat arab, pada kenyataanya tilawah jawi tidak dilafalkan²hal ini dapat dibuktikan dengan mendengarkan setiap huruf yang dilafalkan Yaser pada beberapa surah yang dibaca. ${ }^{3}$ Dua pernyataan dari narasumber kredibel yakni Herman Sinungjanutama dan Irfan Sa'id menyatakan hal yang sama yakni suara Yaser telah memenuhi hakhak huruf dan telah sesuai makhraj-nya.

Sa'id menyatakan bahwa makhraj pada setiap huruf yang dilafalkan Yaser sudah benar dan memenuhi hak-hak hurufnya, jika ada huruf mad yang dirasa terlalu panjang merupakan hak prerogratif dari seorang Qari'. Tempo adalah alasan yang membuat Qari' memiliki keleluasaan untuk mengolah suara dari sisa nafas yang masih panjang (Sa'id, wawancara 30 Juni 2015).

Pernyataan senada juga diungkapkan oleh Herman Sinungjanutama, bahwa makhraj-nya orang Jawa tidak seperti yang dibacakan oleh Yaser. Berikut ini adalah pernyataanya:

“...lah itu Yaser bacanya masih Arab sekali, kalo lidahnya orang jawa tidak begitu. "alamin jadi ngalamin, bismillahirohmanirrohim jadi bismilakhirohmanirokhim..."(Janutama, wawancara 24 Juli 2015).

Berdasarkan pernyataan Herman Sinungjanutama tersebut dapat ditarik benang merahnya mengapa tilawah jawi menjadi kontroversi. Satu sisi pihak yang mendukung adalah pihak yang pro dengan sajian lagu al-Qur'an yang dilantunkan Yaser dan pada sisi lain pihak yang kontra melihat dari sisi hukum tajwid yang harus dipatuhi. Mayoritas yang tidak mengamini bacaan Yaser adalah kalangan yang tidak mengetahui seluk-beluk Seni Tilawatil Qur'an. ${ }^{4}$

Tilawah jawi yang tidak memenuhi makhraj-nya tentu dapat dikategorikan dalam bacaan haram. Pada kenyataanya Yaser mampu memadukan dua unsur tersebut. Dari sisi lagu dan pemenuhan hukum tajwid.Tidak hanya Yaser generasi terbaru yang telah lebih dahulu mengunggah tilawah jawi seperti Ulil Absar Abdala adalah generasi terbaru yang membaca al-Qur'an dengan makhraj yang benar.Tilawah jawi dengan makhraj yang masih "jawa" sampai sejauh ini belum ditemukan, semua narasumber hanya berani merapalkan contoh satu kata saja, hal ini dikarenakan para narasumber yang ditemui tidak mau dikategorikan dalam "perangai yang merongsokkan al-Qur'an". Menurut Herman tilawah jawi versi "makhraj-jawa" terakhir dirapalakan oleh si mbah yang tentu saja sudah meninggal dunia.

\section{f) Warna Suara}

Warna bunyi adalahperbedaan suara pada bunyi. Setiap bunyi memiliki warna bunyi masingmasing. Contoh Ketika sebuah gitar dan organ memainkan lagu yang sama, tentudapat dibedakan suara kedua alat musik tersebut. Meskipun keduaalat musik tersebut memiliki frekuensi yang sama, tetapi bunyi yang dihasilkan oleh kedua sumber bunyi tersebut berbeda.

Seperti yang telah dibabarkan dalam sub bab sebelumnya warna suara Yaser dapat teridentifikasi dari suara yang sedikit sengau, agak serak, memiliki jangkauan nada yang cukup luas mulai dari nada $A b 2$ hingga nada $C \# 5$. Seorang penyanyi biasanya akan dikategorikan suaranya berdasarkan ambitus yang dimilikinya.

Ambitus adalah batas kemampuan seseorang dalam menyuarakan atau menyanyikan wilayah nada sebuah lagu, yakni batas-batas wilayah nada yang dapat dijangkau atau disuarakan oleh seseorang.Jika dilihat dari jangkauan nadanya Yaser dapat dikategorikan dalam dua jenis suara pertama tenor yaitu suara tinggi pada penyanyi perbedaan keduaa dalah bass atau suara rendah untuk penyanyi pria.

Secara umum jangkauan nada padasuara tenor terletakdiantara nada C3 sampai nada A4 dalam paduan suara, sedangkan untuk penyanyi solo dapat mencapai nada C5.Yaser pada kenyataanya memiliki jangkau di atas $\mathrm{C} 5$ yaitu $\mathrm{C} \# 5$. 


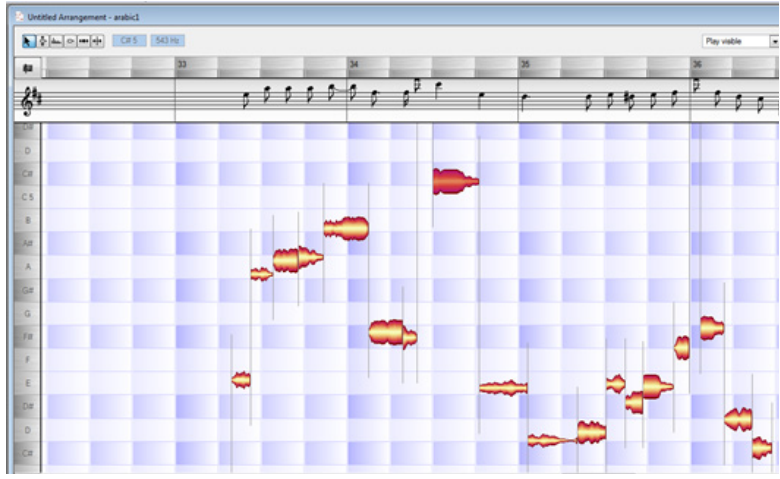

Gambar 7. Suara tertinggi Yaser terletak pada nada C\#5

Kata tenor ${ }^{5}$ juga dipakai oleh beberapa jenis alat musik seperti saxophone untuk mengindikasikan rentang nada yang dihasilkan dari alat music tersebut. Di dalam opera, nada terendah tenor bias sampai ke A2, walaupun hanya sedikit sekali yang lebih rendah dari C3, dan nada tertinggi bias sampai ke C5. Di dalamteatermusikal, nada tenor biasanyaditulisdari B b 2 and A b 4, walaupun kadang ada nada rendahsampai A b 2 dan nada tinggisampai G5.

\section{g) Ketahanan Nafas}

Kalimat lagu dalam al-Qur'an memiliki ketentuan khusus untuk menentukkannya. Berbeda dari jenis seni suara lainnya, ketahanan nafas memegang peranan sangat penting dalam menentukkan sebuah kalimat lagu, aturan taksin, yaknimematikan bunyi huruf pada setiap waqaf, selain memiliki peranan penting terhadap bunyi akhir rima pada setiap ayat yang dibaca. Tujuan dan fungsi utamanya adalah untuk menjaga agar tidak terjadi kekeliruan pemaknaan isi kandungan al-Qur'an.Seperti yang dinyatakan oleh Syeik Fathi Kadil dalam Kristina Nelson berikut ini:

"Aku tentukan pilihan dengan serta merta saja, sesuai dengan makna teks yang ada, tetapi aku harus kembali ke lagu bayaty"6

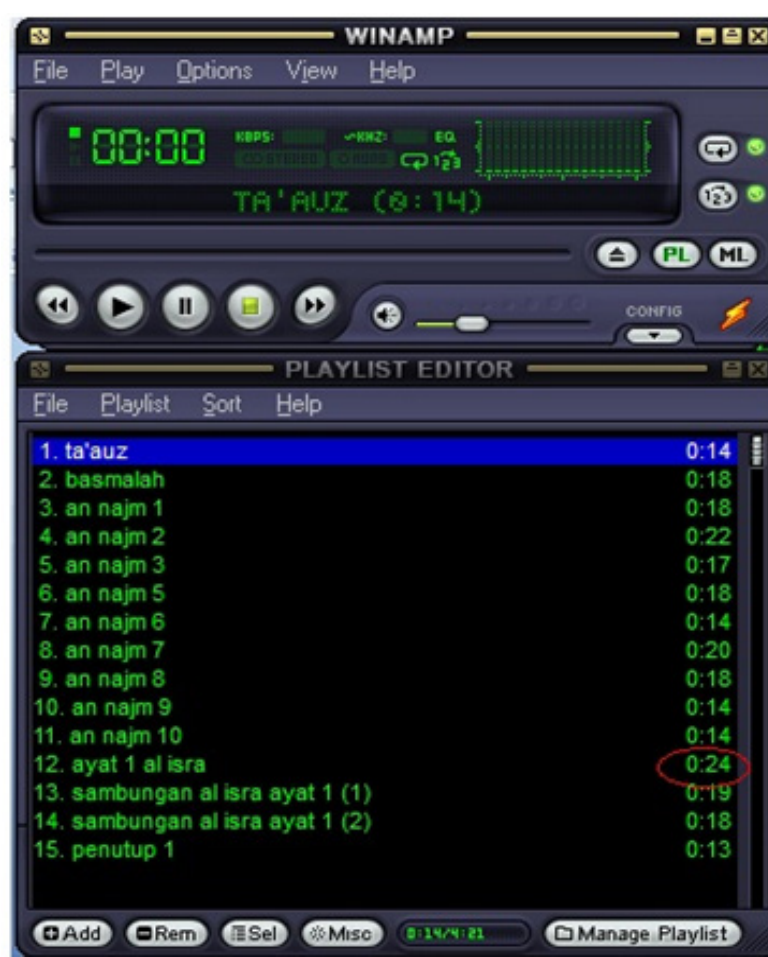

Gambar 8. Detik Yaser dapat Menahan nafasnya dalam satu kalimat lagu

Rekaman audio saat melantunkan tilawah jawi merupakan data utuh yang kemudian dipotong dan dipilah berdasarkan ayat yang dibaca Yaser, setelah melakukan pemisahan, didapatkan data seperti gambar tersebut. Melalui gambar tersebut dapat dilihat Yaser mampu menahan nafasnya selama 24 detik. Data ini bukanlah data satu-satunya untuk mengetahui ketahan nafas seorang Yaser.

Saat melantunkan tilawah arabi, ketahan nafas Yaser dapat rata-rata mencapai 32 detik. Hal ini dikarenakan saat melantunkan tilawah arabi Yaser dapat dengan mudah mengeluarkan perbendaharaan variasi yang dimiliki, sedangkan pada kasus tilawah jawi Yaser belum banyak melakukan ekslporasi, hingga saat ini ${ }^{7}$ Yaser masih terus berlatih.

\section{Analisis Tangga Nada (Register)}

Pelantunan tilawah, seperti halnya dalam musik, penggunaan register tidak terbatas kecuali kapasitas suara dari masing-masing Qari'. Suatu hal yang biasa dalam resitasi mujawwad untuk memulai sebuah penampilan dengan nada rendah, kemudian secara bertahap akan naik ke nada yang lebih tinggi sampai suara tersebut cukup panas, barulah dilakukan penjelajahan kedua register yang diakhiri 
dengan nada rendah kembali. Ciri gaya mujawwad adalah perubahan secara tiba-tiba tangga nada dari satu frase ke frase selanjutnya. Seorang Qari' akan menurunkan register suaranya untuk meredakan ketegangan. Seperti halnya dalam musik, nada tinggi biasanya digunakan untuk menghadirkan ketegangan, kegembiraan dan sebuah klimaks (Nelson, 1985: 123-124).

Melodi yang dilantunkan Yaser dalam tilawah jawi-nya memiliki jarak yang berdekatandan bergerak naik secara bertahap. Berdasarkan analisis yang dilakukan tingkatan suara (tangga nada) pada tilawah jawi Yaser dapat dikategorikan menjadi dua tingkatan saja yaitu sedang dan tinggi, seperti tingkatan nawa dan jawab dalam tangga nadaSeni Tilawatil Qur'an. Selain itu jarak nada satu dan lainnya memiliki jangkah yang hampir sama yaitu, seperti yang terlihat dalam gambar balok berikut ini. $^{8}$

\section{Analisis Melodi}

Penelusuran lebih lanjut mengenai kebenaran dua pernyataan tersebut divalidasi pada telinga yang lebih ahli, yaitu dengan meminta bantuan pada Waluyo 9 . Setelah mendengarkan resitasi tilawah jawi Yaser secara berulang-ulang, akhirnya Waluyo menyimpulkan bahwa laras yang digunakan masih terpengaruh nada-nada diatonis, namun setelah diperlihatkan penulisan notasinya, Waluyo menyimpulkan bahwa ini hampir dapat dinyatakan pelog nem (Waluyo, wawancara September 2015).

Pernyataan Waluyo tersebut dilandasi nada nem dan ji yang seringkali muncul dalam setiap awal resitasi Yaser. Dua nada tersebut memiliki kriteria untuk dapat dinyatakan sebagai pelog nem. Salah satu contoh nada yang masuk kategori pelog nem.

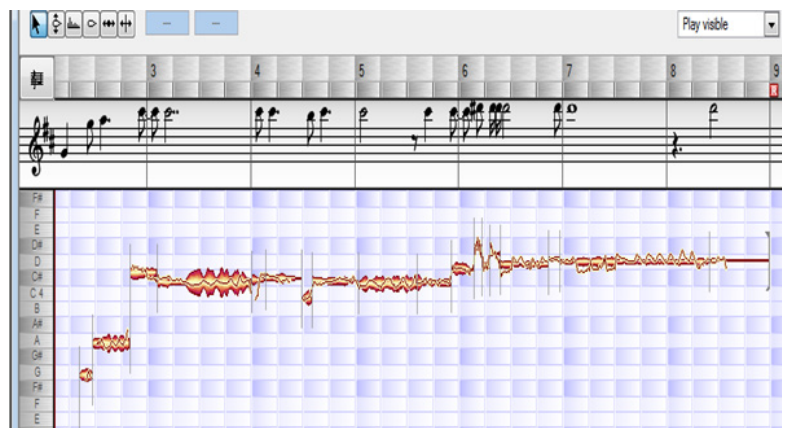

Gambar 9. Dua nada tersebut memiliki kriteria untuk dapat dinyatakan sebagai pelog nem

Berdasarkan hasil analisis yang dilambari pernyataan Waluyo tersebut dapat disimpulkan bahwa, sesungguhnya nada-nada yang terlibat dalam resitasi tilawah jawi Yaser adalah pelog nem yang kualitasnya sudah berkurang, dinyatakan berkurang karena nada alternatif seperti nada pat dan pi belum terdeteksi dalam resitasi tilawah jawi Yaser, oleh karena itu cukup relevan jika laras pelog yang digunakan Yaser diberi predikat pseudo laras pelog.

Yaser sampai hari ini masih ragu untuk memberikan predikattilawah jawipada bacaannya. Meskipun Menteri Agama Indonesia telah mendapuk Yaser untuk membacakannya di Istana Negara pada tanggal 15 Mei 2015, dan di Istana Wakil Presiden pada tanggal 26 Maret 2015. Hal ini tentu disadari Yaser, karena pada kenyataanya Yaser memang tidak dapat mengimplementasikan unsur musik Jawa secara utuh kedalam resitasinya. Yaser hanya mampu mengadobsi nada-nada pokok yang ada dalam laras pelog. Berdasarkan pengukuran frekuensi nada yang dilakukan tampak bahwasannya Yaser hanya mengaplikasikan nada mi, fa, sol, si, do yang ada dalam musik diatonis (barat) atau nada-nada dalam sistem maqam ajam dalam tilawah arabi. ${ }^{10}$ Hasil pengukuran frekuensi dapat dilihat dalam tabel berikut.

Tabel 2. Frekuensi masing-masing nada al-isra

\begin{tabular}{|c|c|c|}
\hline Nama & Nada & Frekuensi \\
\hline \multirow{3}{*}{$\operatorname{Nem}(\mathrm{nm})$} & $\mathrm{A} 2$ & 109,43 \\
\hline & $\mathrm{A} 3$ & 219.84 \\
\hline & A4 & 439.46 \\
\hline \multirow{2}{*}{$\begin{array}{l}\text { Penunggul } \\
\text { (Pn) }\end{array}$} & $C \ddagger 3$ & 136.99 \\
\hline & $\mathrm{C} \pm 4$ & 277,94 \\
\hline \multirow[t]{2}{*}{ Gulu [Gl) } & D3 & 146.92 \\
\hline & D4 & 293.73 \\
\hline \multirow[t]{2}{*}{ Dadha(dd) } & E3 & 164.85 \\
\hline & $\mathrm{E} 4$ & 329.79 \\
\hline \multirow{3}{*}{$\begin{array}{l}\text { Limo } \\
(\operatorname{lm})\end{array}$} & $\mathrm{G} \neq 2$ & 103.89 \\
\hline & $\mathrm{G} \neq 3$ & 206.85 \\
\hline & $G \div 4$ & 415,44 \\
\hline
\end{tabular}

\section{Jangkah}

Tabel 3. Jangkah masing-masing nada dan jangkah setiap gembyang surah al-Isra 


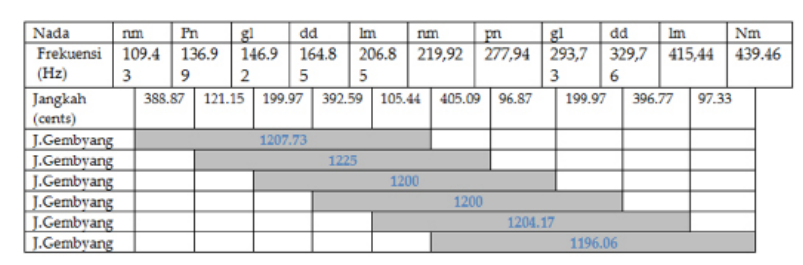

Tabel 5.Ratio Gembyang Surah al-isra

\begin{tabular}{|c|c|}
\hline Gembyang Nada & Ratio Gembyang \\
\hline Nem Gembyang 1 & 2.018 \\
\hline Penunggul Gembyang 1 & 2.029 \\
\hline Gulu Gembyang 1 & 2 \\
\hline DodhoGembyang 1 & 2 \\
\hline Limo Gembyang 1 & 2.004 \\
\hline Nem Gembyang 2 & 1.995 \\
\hline Penunggul Gembyang 2 & 1.992 \\
\hline Gulu Gembyang 2 & 1.996 \\
\hline Dodho Gembyang 2 & 1.996 \\
\hline
\end{tabular}

Hasil pengukuran frekuensi tersebut adalah bukti bahwasannya bacaan Yaser masih belum layak dikatakan laras pelog nem, karena pada kenyataanya ratio masing-masing jangkah pada setiap gembyang menunjukkan hasil yang mendekati angka 2, bahkan pada beberapa gembyang seperti yang tertera pada tabel-tabel tersebut, diketahui ada gembyang yang dapat dikatakan pleng atau persis, dalam sistem pelarasan karawita Jawa hal ini tidak akan terjadi, menurut Hastanto Gamelan yang baik akan memiliki jangkah gembyang di atas 1200 atau digoyang ke atas. Hastanto menjelaskan bahwa Karawitan Jawa memiliki sifat atau watak pelarasan sendiri yang berbeda dengan musik lainnya yaitu ngeng $^{11}$.

Kualitas seorang Qari' sangat ditentukan oleh melodi yang dihasilkan. Menurut Irfan Sa'id, sebagai seorang Qari' sa'id mengatakan bahwa tilawah jawiYaser dianggap cukup merdu untuk dinikmati lagunya, namun secara pribadi Sa'id menyatakan ia lebih nyaman menggunakan lagu arab (Bayyati, Hijaz, Nahawand dan sebagainya). Pendapat lain dinyatakan oleh Shinden wanita bernama Pujiani, yang mengatakan bahwa tilawah jawi Yaser nadanya hanya dihias dengan teknik $l u k$ saja sedangkan teknik gregelbelum terjangkau oleh Yaser, seperti apa yang dinyatakan Pujian berikut ini.

“...iki gak ono gregele kok, mung luk tok..." (Pujiani, wawancara 20 Juli 2015).

Teknik lukdilakukan oleh Yaser saat bertemu dengan huruf yang berharakat lebih dari satu seperti yang tergambar dalam notasi kepatihan berikut ini.

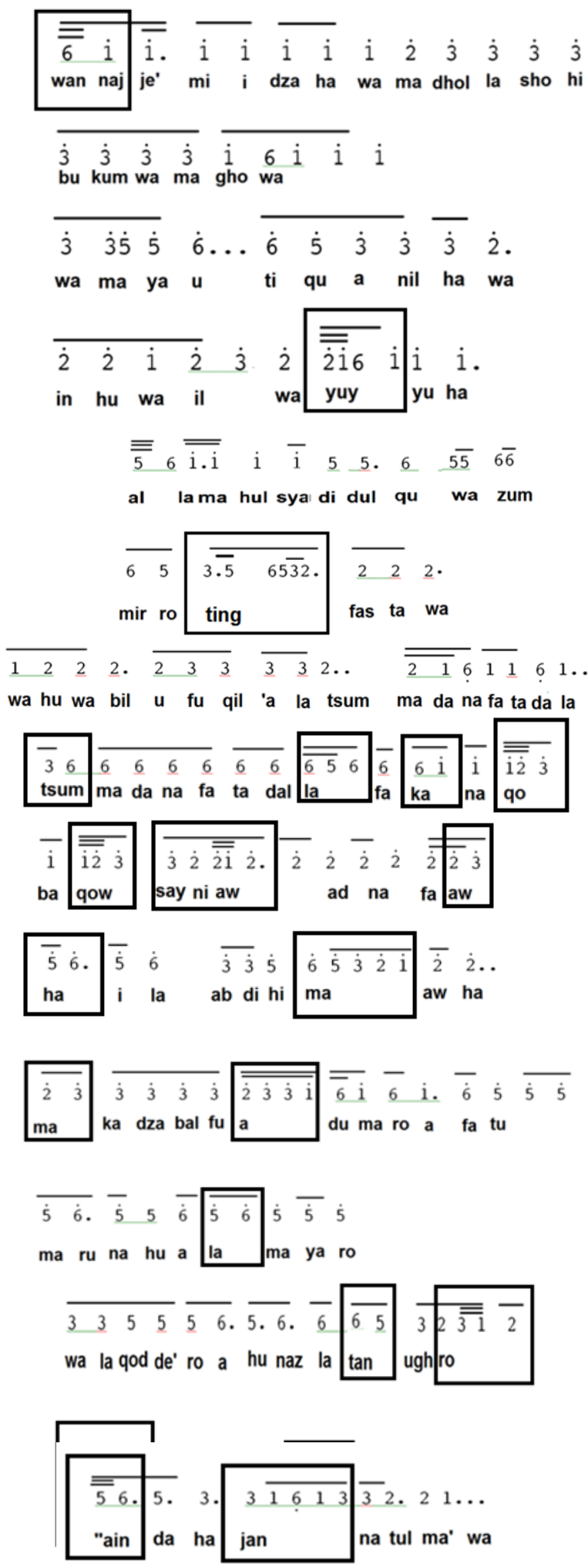

Gambar 10. Notasi Kepatihan Surah An-Najm 
Variasi melodi Yaser tidak dapat diidentifikasi dengan pasti, namun jika dilihimpun lintasan nadanya, Yaser paling sering meracik nada nem dan ji dalam tilawahnya. Pengolahan nada-nada yang menjadi modal Yaser dalam tilawahnya dirapalkan dengan cara beragam, tidak terdapat alur melodi khusus yang dapat dibaca dari resitasi tilawah jawi Yaser, namun ada satu hal yang menjadi ciri khas dari seorang Yaser, yaitu penggunaan nada nem dan ji untuk mengawali resitasi, biasanya dilakukan pada teks awal yaitu ta'auz. Seperti yang tertera pada tabel berikut ini:

\section{Analisis Tempo}

Dua gaya dalam resitasi al-Qur'an, dapat diketahui dengan mudah melalui tempo. Mujawwad memiliki tempo lebih lambat dibandingkan dengan resitasi murottal. Saat melakukan perekaman tilawah jawi Yaser. Terdapat empat tingkat kecepatan dalam membaca al-Qur'an yaitu Tahkik, Tartil, Tadwir dan Hadar. Tahkik adalah kecepatan bacaan seperti tartil tetapi lebih lambat dan perlahan. Tingkat kecepatan ini biasanya dilaksanakan bagi mereka yang baru belajar membaca al-Qur'an. Tartil adalah bacaan perlahan-lahan, tenang ketika melafazkan huruf-huruf daripada makhrajnya disertai dengan memberikan hak (sifat semula jadi huruf) dan mustahaknya (sifat-sifat yang mendatang) serta bertadabbur dengan maknanya. Hadar adalah bacaan dengan tingkat kelajuan paling cepat serta tetap menjaga seluruh hukum tajwid dan biasanya diamalkan oleh orang yang mentasmik hafazan di depan gurunya. Tadwir adalah tingkat kecepatan bacaan pertengahan di antara bacaan tartil dan hadar. Pada aras ini bacaan Yaser masuk dalam kategori bacaan yang tartil.

Rangkaian melodi dalam Seni Tilawatil Qur'an tentu saja didasari dari apa yang dibaca, maksudnya adalah bahwa melodi yang terangkai berasal dari teks yang dibaca yaitu berdasarkan aturan tajwid. Panjang pendek setiap suku kata yang dibaca dapat ditentukan sesuai kebutuhan bacaan. Tidak ada ketentuan khusus mengenai akurasi harga nada (ketukan). Enam harakat yang dibaca tidak dapat diakurasikan dengan enam ketuk (seperti ketentuan harga nada dalam musik pada umumnya), hal ini disebabkan karena dalam pelantunannya seringkali sang Qari' mengubah temponya secara tiba-tiba. Perubahan tempo secara tiba-tiba tidak disalahkan dalam seni tilawatil Qur'an, karena Qari' mendapatkan kebebasan mengatur kecepatan bacaanya sesuai dengan ketahanan nafas dan kemampuannya.

\section{Analisis Qira'at}

Seorang Qari' tilawahsering melakukan variasi qira'at, di Mesir qira'at yang sering terdengar setelah bacaan standar hafsan asimadalah qira'at hamzahdan warsy, jenis qira'at ini juga yang digunakan mayoritas umat Muslim Indonesia termasuk yang digunakan Yaser saat di istana negara. Karakter qira'at ini mudah dikenali, bahkan oleh pendengar yang kurang kurang begitu memahami bacaan alQur'an. Yaser dalam resitasinya tidak melakukan variasi qira'at hal ini dilakukan demi kenyamanan pelafalan bagi Yaser sebagai Qari' dan audien yang mendengarkantilawah jawi. Penggunaan qira'at hafs an asim juga dipertimbangkan karena mayoritas umat muslim Indonesia membaca dengan qira'at ini. Perbedaan menonjol dari jenis qira'at ini adalah persoalan saktah.

Saktah Secara bahasa saktah berasal dari kata اتوكس - تكسي - تكس yang berarti diam; tidak bergerak, atau bisa juga bermakna عندل (mencegah). Sedangkan menurut istilah; (memutus kata sambil menahan nafas dengan niat meneruskan bacaan).Dalam qira'at as Sab'a bacaan saktah banyak dijumpai pada qira'ah Imam Hamzah (baik dari riwayat khalaf maupun khalaf), yaitu setiap ada hamzah qatha' yang didahului tanwin atau al ta'rif, seperti ميلبأبعة . Sedangkan dalam qira'ah Imam Ashim riwayat Hafsh, bacaan saktah dalam al-Qur'an hanya ada di empat tempat, yaitu pada alif gantian dari tanwin yang terdapat pada lafazh اجوع dalam surat al Kahfi ayat 1-2, pada alif yang terdapat pada kalimah أندَقْْرَ dalam surat Yasin ayat 52, pada Nun-nya lafazh نْdalam surat al Qiyamah

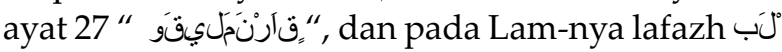
dalam surat al Muthoffifin ayat 14 ;

Selain empat tempat di atas, sebetulnya ada dua lagi saktah umum yang diikuti oleh Imam Ashim, yaitu pertemuan antara surat Antara surat al Anfal dan surat at Taubah pada Mim-nya lafazhe'pe", pertemuan dua ha' pada kalimat (dalam surat al-

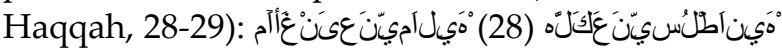

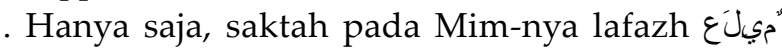
ini sebenarnya satu diantara tiga alternatif bacaan yang disepakati oleh semua imam qira'at, yaitu washal, saktah dan waqaf dan pada surat al-Haqqah sebenarnya satu diantara dua alternatif bacaan, yaitu Idgham dan saktah. 
Seperti yang telah dijelaskan dalam sub bab analisis repitisi dan pemisahan teks pada surah alIsra dan an-Najm bahwa tidak terjadi pengaburan makna, dengan kata lain qira'at yang diterapkan Yaser mematuhi hukum saktah yang diterapkan dalam qira'at Hafs an Hasim dengan benar.

Menurut Herman Sinungjanutama tilawah jawi dilafalkan dengan lidah Jawa yang dapat dinyatakan tidak memenuhi hak-hak hurufnya, seperti apa yang dinyatakan oleh Herman berikut ini.

"tilawah jawi itu ndak gitu tapi dibaca dengan ilat Jawa, seperti waladolin yang dikeluarkan tanpa mengembungkan pipi, ngalamin untuk melafalkan huruf 'ain" (Janutama, wawancara 24 Juli 2015).

Yaser dalam resitasinya menerapkan ilmu qira'at hafs an nasm yang dikeluarkan dengan menerapkan hukum tajwid yang telah memenuhi hakhak huruf beserta sifatnya (Said, wawancara 5 Juni 2015).

\section{Analisis Tajawub}

Sajian tilawah selalu dibawakan secara live performance, berhadap-hadapan langsung dengan para pendengarnya, hal ini merupakan bagian penting bagi seorang Qari' karena melalui ini, Qari' bisa mendapatkan informasi serta meningkatkan kemampuan musiknya, seperti yang diungkap oleh Syekh Mustafa Isma'il berikut ini:

“...diantara pendengar itu ada musisi dan artis. Mereka berkata oh dia sedang (memakai) lagu bayati. Bagaimana jika memamaka saba'. Demikian saya belajar. Saya mendengarkan komentar mereka. Saya biasa membaca setiap malam, dan mereka selalu ada di sana..."12

Tajawub artinya saling bersijawab. Saat sedang tilawah, sang Qari' seolah sedang bertanyakepada para Auidendimintauntukmenjawabnya. Ungkapan tajawub beragam, yang paling sering diungkapkan adalah: Allah! Allah!, Hayyakallah! (Allah! Allah! Semoga Allah menghidupkanmu!). Aktivitas ini adalah tajjawub dua arah sedangkan aktivitas tajawub satu arah dapat ditemui imam membacakan surah alFatiha yang dijawab Amin oleh para makmum.

Sejak awal tilawah jawi disajikan, tidak ada aktivitas tajawub. Para audien memiliki sikap hampir sama yakni duduk diam mendengarkan tilawah jawi Yaser dan tidak ada respon lain seperti mengucapkan kata sanjungan dengan melafaskan nama Allah SWT, di tengah-tengah bacaan, setiap saat satu frasa selesai dibacakan.

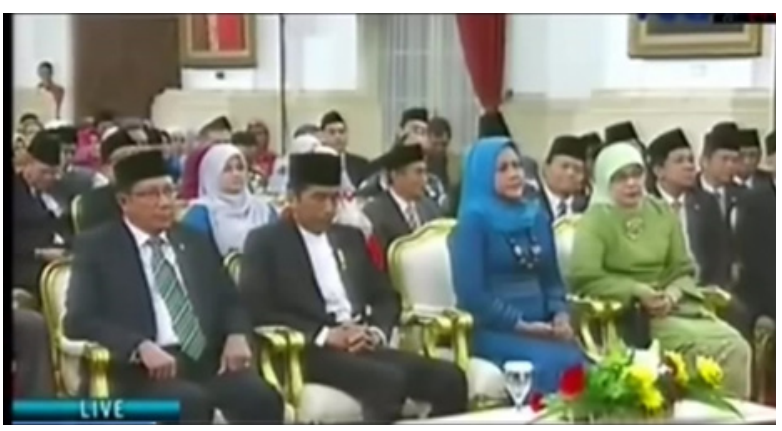

Gambar 12. Para Audien saat mendengar Tilawah Jawi Yaser saat acara Isra' Mi'raj di Istana Negara 2015

\section{Analisis Ekspresi Yaser dalam Pertunjukkan}

Secara keseluruhan ekspresi yang ditampakkan oleh Yaser adalah sikap yang tenang dan santai, kekhusyukan Yaser terlihat dari ekspresinya yang sering memejamkan mata. Setiap huruf vokal A, I, $\mathrm{U}$ dan $\mathrm{O}$ selalu dilafalkan dengan menarik bibir secara maksimal seperti pelafalan "I"Yaser menarik bibirnya kebelakang dengan pelafalan huruf " $U$ " yang diucapkan dengan sedikit memajukan bibir bagian bawah yang tampak dalam gambar berikut.

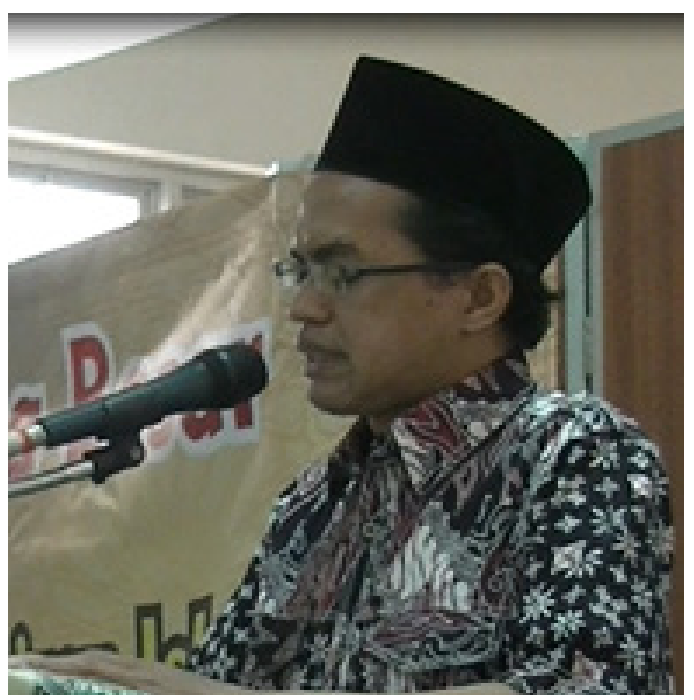

Gambar 13 . Bentuk Bibir Yaser saat melafalkan huruf I 


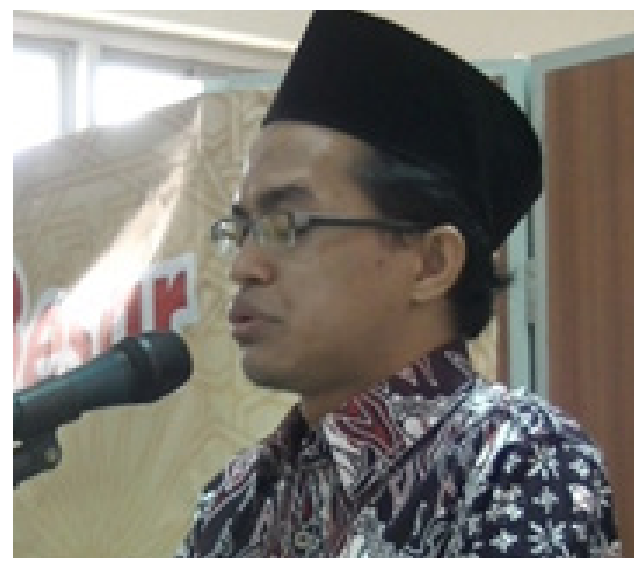

Gambar 14.Bentuk bibir Yaser saat melafalkan huruf U sambil memejamkan mata

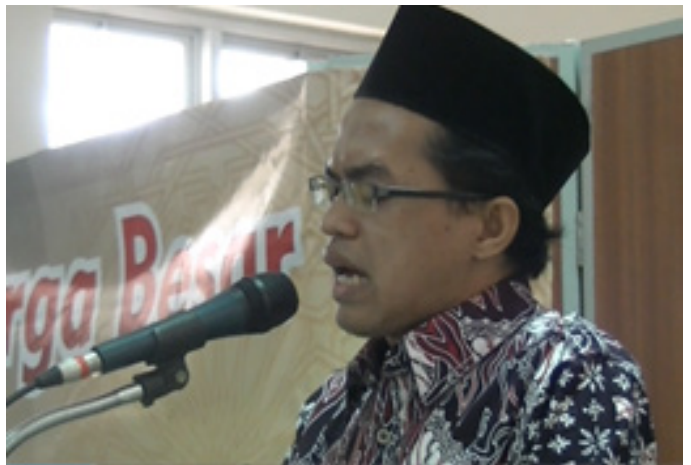

Gambar 15. Bentuk Bibir Yaser saat melafalkan huruh A

Yaser dalam resitasiny seringkali menarik nafas dengan mencondongkan kepala dan bagian badannya ke belakang seperti yang terlihat pada gambar berikut ini.

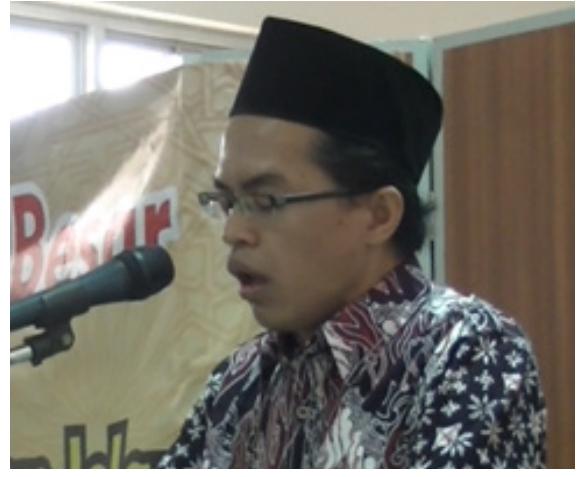

Gambar 16. Bentuk bibir Yaser saat menarik nafas Secara keseluruhan sikap yang ditampilkan Yaser adalah rileks dan tenang, tidak ada perbedaan sikap Yaser terhadap jumlah Audien maupun tempat di mana tilawah jawi disajikan. Saat di istana negara yang banyak disorot media . sekalipun

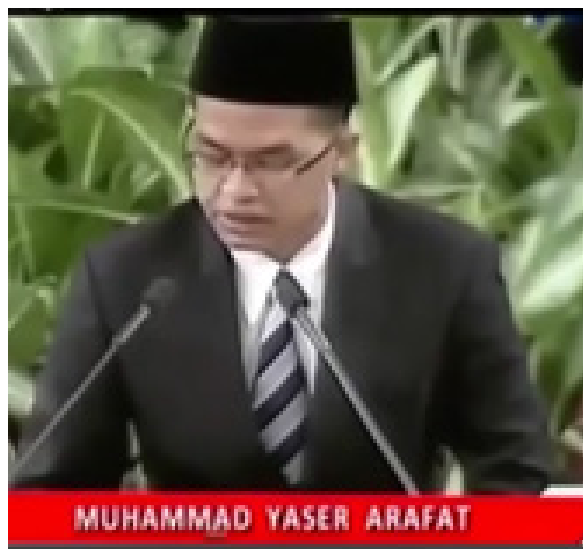

Gambar 17. Sikap rileks Yaser saat membawakan tilawah jawi

\section{B. Yaser, Tilawah Jawi dan Jalan Menuju Tuhan}

“...Tilawah jawi yang saya baca merupakan hasil dari perjalanan ilmiah dan batiniah yang sangat panjang. "Yang batiniah" tentu urusan saya... (Yaser wawancara 4 Juli 2015)."

“...Saya akan sedikit menceritakan sepicis dongeng setelah tidur tentang hubungan saya dan tilawah jawi. Agar ada persambungan rasa dan perikatan suara antara kita. Perlu saya tegaskan bahwa saya bukanlah orang pertama yang bertilawah-jawi. Jauh sebelumnya, di pelosokpelosok desa di Jawa, ada banyak simbah-simbah dan orang-orang sepuh imam masjid setempat yang telah menindakinya...(Yaser wawancara 4 Juli 2015)."

Pada tahun 2012, Yaser menemukan rekaman bacaan al-Qur'an berlanggam Jawa di situswww. soundclouds.com, yang diunggah oleh akun Ulil Abshar-Abdalla. Seorang tokoh Jaringan Islam Liberal (JIL) itu menyebut bacaannya sebagai Murattal Jawa..$^{13}$ beberapa surat diunggah di sana. Ada surat Maryam, Surat ar-Rahman, Surat alBaqarah (Juz 1), dan Juz 'Amma. kemudian bacaan Murattal Jawa tersebut diunggah ke situs www. youtube.com, yang ditonton oleh cukup banyak oleh para netizen. Mencapai 3 ribu lebih ${ }^{14}$-dan pasti akan terus bertambah. Menurut Yaser, Ulil adalah orang pertama yang merekam tilawah jawi dan mengunggahnya ke dunia maya (Yaser wawancara 4 Juli 2015).

Pembacaan al-Qur'an turut menentukan 
proses pengasahan rasa manusia, dalam hal ini berlaku pada umat Islam. Seseorang yang terbiasa mendengar nada-nada indah, bercitarasa spiritual, dan bernuansa meditatif-reflektif ( $\left.k h u s y u^{\prime}\right)$, niscaya batinnya akan terasah dengan sendirinya. Usaha untuk membentuk generasi peka kebenaran juga akan lebih mudah diamalkan. Para wali songo dan ulama-ulama dahulu telah menyedekahkan suri teladan tentang tersebut. Satu di antara banyak cara untuk membatinkan Islam, sebagaimana mereka suarkan, adalah dengan mengemas ajaran-ajaran Islam ke dalam nada-nada, nyanyian, suluk, tembang, dan aneka estetika-spiritual lainnya. Berkaca dari sana, tilawah jawi layak mendapatkan tanda pengenal sebagai pilar penyangga kelestarian ajaran Islam di Nusantara.

Tilawah jawi bagi Yaser ikut menentukan apakah pembacaan al-Qur'an dapat menjadi amal terkarib umat Islam di tengah pepetan "bunyi" dan nada-nada komersial dunia modern yang bercorak industrial, homogen, dan monoton. Tilawah jawi di sini hadirmenjadi terapi budaya audial bagi telinga yang terbiasa dengan nada-nada populer yang hampir seluruhnya diproduksi dengan asas-asas semangat industrial. Bukan rahasia lagi, jika peradaban bunyi manusia Indonesia telah dihikmati sebagai elemen industri- ekonomi (Yaser, wawancara 4 Juli 2015).

Lebih lanjut Yaser menambahkan alsannya menggunakan laras Jawa dan tetap mempertahankan nama tilawah jawi sebagai gaya tilawahnya. Bagi Yaser, tilawah jawi adalah pernyataan anak bangsa yang ingin memakrifati sejarahnya sendiri. Tilawah jawi adalah rasa terima kasih Yaser kepada para leluhur Awliya yang telah berjuang mati-matian mengenalkan Allah SWT dan Rasulullah SAW secara bersambung hingga hari ini. Baik secara lahiriah maupun batiniah (kasyfi). Entah dengan nada-irama syair, tembang, karya sastra, dan do'ado'a.

Bagi Yaser tilawah jawi adalah tempat menitipkan asa di tengah himpitan nada-nada Arab yang digunakan para Qurro' ${ }^{15}$ dalam belajar Seni Tilawatil Qur'an untuk berlomba menjadi juara dan mendapat hadiah. Realitas ini dianggap Yaser sebagai 'penyimpangan tujuan', karena tujuan pembacaan tilawah adalah untuk diamalkan bukan sekedar untuk dinikmati keindahan bunyinya. Yaser secara tegas menyatakan bahwa lebih nyaman menggunakan unsur musik Jawa daripada unsur musik Arab, karena Yaser merasa dapat menyelamkan pendengarnya ke dasar samudera ketenangan, suasana meditatif, dan atmosfer reflekti, seperti yang dinyatakan Yaser berikut ini.

“...Bagaimana dengan tilawah jawi? Saya tidak berintensi untuk mengunggulkannya. Bagaimanapun, ia karya seni yang tidak kedap kritik. Hanya saja, saya berani untuk menitipkan asa kepada tilawah jawi. Ia bisa dijuluki budaya tanding (counter culture). Karena dalam persabungan nada-nada mutakhir, tilawah jawi saya anggap mampu untuk mengisi kerusuhan rasa dan kerisihan jiwa manusia yang diakibatkan oleh karnaval nada- nada industrial. Sebagaimana Sekar Macapat, bila tilawah jawi diperdengarkan, ia bisa menyelamkan pendengarnya ke dasar samudera ketenangan, suasana meditatif, dan atmosfer reflektif. Tentu dengan catatan bahwa ia diperdengarkan kepada telinga yang hidup dalam kebudayaan tempat tilawah jawi itu pernah tumbuh. Jika tidak, setidaknya tilawah jawi dapat disuarakan untuk menginterupsi riuh-ricuh nada-nada mesin industri..."16( Yaser, wawancara 4 Juli 2015).

Pernyataan Yaser juga dinyatakan oleh Anne $\mathrm{K}$ Rasmussen yang menyebutkan dengan istilah festivalization and staging religion (festivalisasi dan agama pentas). Ada banyak anak-anak umat Islam yang mempelajari tilawah arabi tidak untuk mengasah kepekaan spiritualnya, melainkan untuk mengikuti ajang MTQ. Terlebih lagi perlombaan dengan hadiah besar yang dijanjikan.

“...Saya menemukan banyak sekali data tentang kekotoran dalam dunia MTQ. Sehingga, wajar bila Mbah Arwani dari Kudus, Jawa Tengah, mengharamkan santri-santri yang belajar al-Qur'an kepada beliau untuk ikut MTQ. Karena itu pula, saya menolak usul Menteri Agama Lukman yang pernah berencana untuk memasukkan "tilawah langgam lokal" dalam MTQ. Namun, saya mendukung penuh bila tilawah lokal hendak diinventarisasi, dikonservasi, dan bahkan ditradisikan kembali..."(Yaser, wawancara 4 Juli 2015).

Tilawah Jawi juga merupakan rasa syukur Yaser kepada Allah SWT karena telah ditempatkan untuk hidup di bumi Nusantara yang di sanalah air sumur ternikmat dunia diminum, udara tersejuk jagad raya saya hirup, sayuran tersegar alam semesta saya santap, nasi tergurih alam fana saya telan, dan bumi tersubur galaksi ini saya nikmati (Yaser, 21 Agustus 2015).

Tilawah jawi juga merupakan sikap pemihakan 
Yaser pada orang-orang yang terpinggirkan dan dipinggirkan oleh laju ekonomi yang terpusat di kota-kota besar. Para leluhur mereka dahulu yang telah lebih dahulu ber-tilawahjawi. Namun, kini, anak-cucu mereka yang telah dipinggirkan itu semakin berada di pinggir. Sebab tanah-tanah mereka telah dibeli oleh kumpulan orang-orang kaya yang berkeinginan untuk meraup keuntungan ekonomi berlebih dengan membangun mal, hotelhotel, apartemen, lapangan golf, dan tempat-tempat bisnis skala internasional. Lalu, sumur mereka mengering kering-gering. Sumber-sumber mata air mereka (sendang, belik) yang telah memuncar sejak era para leluhur mereka dahulu, pun telah diambil-alih pengelolaannya oleh perusahaan air minum dan atau perusahaan semen milik entah siapa (Yaser, wawancara 4 Juli 2015).

\section{SIMPULAN}

Nada-nada yang dirangkai Yaser pada kenyataanya tidak dapat dikatakan sebagai nada Jawa seutuhnya terutama mengkategorikannya dalam laras pelog, namun berdasarkan hasil pertimbangan dan analisis yang mendalam ${ }^{17}$ diketahui bahwa bacaan Yaser dapat dimasukkan dalam kategori laras pelog nem karena kemiripan jangkah yang dimilikinya. Jadi tepat kiranya jika laras yang digunakan Yaser diberikan predikat pseudo pelog nem, artinya pelog nem yang kualitasnya telah berkurang. Kualitas berkurang karena jangkah yang dinyatakan Yaser dalam setiap nada hanya mampu menyentuh nada-nada pokok dalam laras pelog yaitu 6,1,2,3,5, sedangkan nada 4 tidak terjangkau oleh Yaser.

\section{Catatan Akhir}

${ }^{1}$ Mahasisswa program pascasarjana, jurusan penciptaan dan pengkajian Seni, minat musik Nusantara Institut Seni Indonesia Surakarta.

2 'sebagai contoh "alamin menjadingalamin

${ }^{3}$ Buka file audio

${ }^{4}$ Lihat komentar di alamat ini https://www.youtube.com/watch?v=QL7CibTVZGc, https://www. youtube.com/watch?v=Zp7rNZfJwmc

https://www.youtube.com/watch?v=amnSgEMfX8Y

https://www.youtube.com/ watch? $v=j Z A T I C c m X M U$

${ }^{5}$ Kata tenorberasaldaribahasalatintenere yang berartimenahan. Dalam polifoni abad pertengahan dan Renaissance antarasekitar 1250 dan 1500 tenor merupakan suara dasar yang dijadikan rujukan untuk menentukan suara-suara yang lain.

${ }^{6}$ Baca Kristina Nelson, The Art of Reciting (1988:125131).

${ }^{7}$ Agustus 2015

${ }^{8}$ Dalam gambar notasi balok sengaja tidak menampilkan ayatnya, detail pelafalan huruf dan nada akan ditampilkan dalam notasi kepatihan. Penotasian ini ditampilkan hanya untuk memberikan visual secara grafik

${ }^{9}$ Beliau adalah pengajar paling kredibel di jurusan karawitan dalam menjelaskan seluk beluk seni vokal Jawa, hal ini dinyatakan oleh beberapa Pengajar yang ada di ISI Surakarta serta para mahasiswa Karawitan ISI Surakarta. Lihat daftar Narasumber! ${ }^{10}$ Lihatlagi sub babmaqamajam

${ }^{11}$ Lihat Ngeng dan Reng, Persandingan Sistem Pelarasan, Gamelan AgengJawa Dan Gong Kebyar Bali. Surakarta:ISI SurakartaPress, 2012.

${ }^{12}$ Lihat Kristina Nelson, "Reciter and Listener: some factors Shaping the Mujawwad. Stle of Qur'an Reciting, dalamEthnomusicology 26, 1, 1982.

${ }^{13}$ Karena Ulil adalah tokoh JIL, maka tilawah jawi kerap dikaitkan dengan persebaran faham liberalisme.

${ }^{14}$ Juli2015.

${ }^{15}$ Bentuk jamak dari Qari'

${ }^{16}$ Rangkuman panjang dari hasil wawancara pada tanggal 2 Juni hingga 15 September.

${ }^{17}$ AnalisisdilakukandenganbapakWaluyo Sastro Sukarno, Dosen ISI Surakarta.

\section{KEPUSTAKAAN}

Akbar, AbulHaris. 2009. “Musikalitas Al-Quran (Kajian Unsur Keindahan Bunyi Internal dan Eksternal)", Skripsi. Yogyakarta: Jurusan Tafsir-Hadis Fakultas Ushuluddin UIN Sunan Kalijaga Yogyakarta.

Gade, AnnaM. PerfectionMakes Practice: Learning, Emotion, and the Recited Quranin Indonesia USA: Universityof Hawai'i Press,2004.

Geertz, Clifford. Abangan, Santri, Priyayi dalam Masyarakat Jawa.Jakarta: Pustaka Jaya, 1981.

Hastanto, Sri, Konsep Pathet dalam karawitan Jawa. Surakarta: InstitutSeniIndonesiaSurakartaPress,2009.

Kajian MusikNusantara-1.Surakarta: Institut Seni IndonesiaSurakartaPress,2011. 
Ngeng dan Reng, Persandingan Sistem Pelarasan, GamelanAgengJawa DanGongKebyarBali. Surakarta:ISI SurakartaPress,2012.

Maslow, Abraham H., Motivasidan Kepribadian, Teori Motivasi dengan pendekatan Hierarki Kebutuhan Manusia. Jakarta: PT. Pustaka Binaman Pressindo,1994.

Nelson, Kristina. The Art of Reciting The Qur'an. Cairo: The American University in Cairo Press, 2001.

"Reciter and Listener: Some Factors Shaping The Mujawwad Style of Quranic Reciting", dalam Jurnal Ethnomusicol$o g y$, University of Illionis Press and Society for Ethnomusicology, Vol. 26, No. 1, Januari, 41-47. 1982.

Touma, Habib Hassan ,The Music of The Arabs. Portland,OR: Amadeus Press,1996.

Rasmussen, Annek. “The Qur'an in Indonesia Daily Life: The Public Poject of Musical Oratory" dalam ethnomusicology, vol.45 No.1 2001.

Sukerta,PandeMade,"Perubahan Dan Keberlanjutan DalamTradisi Gong Kebyar: Studi Tentang Gong Kebyar Buleleng". Denpasar: Disertasi Program Pascasarjana Universitas Udayana Denpasar,2004.

Waridi, “Mengkaji TokohSeni Pertunjukkan: Mengapa dan Bagaimana", dalam Menimbang Pendekatan Pengkajian dan Penciptaan Musik Nusantara. Surakarta: Jurusan Karawitan Bekerjasama Dengan Pendidikan Pascasarjana dan STSI Press, 2005.

Gagasan dan Kekaryaan Tiga Empu Karawitan, Pilar Kehidupan Karawitan Jawa Gaya Surakarta 1950-1970-an, Ki Marta pengrawit, Ki Tjakrawasita, Ki Nartasabda. Bandung: Etnoteater Publisher, 2008.

Wirid Lukitadjati: Luludaning Ilmu Kabatosan. Yogyakarta: Badan Penerbit Soemodidjojo Maha Dewa, 1954.

\section{DAFTAR NARA SUMBER}

Irfan, Said umur tidak diketahui, Qari', pegawai Departemen keagamaan Gunung Kidul.

Herman Sinung Janutama (50) Tahun, Budayawan. Sapen GK I No. 358 Yogyakarta

Imam Al-Ghazali (34)Jalan Watu Ulo, RT2.RW1. Bedengan Tegal Sari Ambulu Jember Jawa Timur

Moh. Sahid Joleno (53), Seniman Ketoprak, Jalan Samudra Pasai, Ngipang RT.03 RW 28 Kadipiro Banjarsari, Surakarta.

Muhammad Yaser Arafat (32), Dosen Universitas Islam Negeri Sunankalijaga Yogyakarta. Pernah tinggal di Brebah saat ini tinggal di Medan dan menjadi Dosen tetap di Universitas Islam Negeri Medan.

Waluyo Sastro Sukarno (54), Dosen ISI Surakarta. Kapringan, RT.2 RW.20. Jebres Surakarta. 